\title{
MYTHS OF EMPIRE IN CONTEMPORARY EUROPEAN CULTURE: HISTORICAL CAUSES AND POLITICAL MAPS
}

\author{
Iuliia Gudova \\ Ms., Ural Federal University, Russia, jgudova@mail.ru \\ ${ }^{*}$ Corresponding author
}

\begin{abstract}
It's very important to research the myth of empire and mode which the myth of empire was actualized in early XXI century and how this myth functions now. There are a lot of countries in the Europe which position themselves as the Empire or inheritors of the Empires. All of these countries pretend to the political, cultural and economic domination in the Europe now. This process takes place after The Fall of the Berlin Wall and after many years in The European Union. This paradox fact is very interesting for scientific understanding.

Where are roots of Empire's Myth? What is a cause of Empire's myth actualization in contemporary culture?

The theory of cultural and political myth by R. Bart, M. Eliade, K. Gadjiev and E. Meletinsky would play the role of theoretic and methodology foundation for the myth of Empire cognition. According to these scientists, The Empire's myth is the narrative about Empire. Key idea consists in the statement that all contemporary European countries inherit the territory and myth's consciousness of early Empires in European History. The myth of Empire is narrative about that Empire's land where ancestors lived. That Empire of ancestors does not exist in the real everyday life, but the myth of Empire continues to live in the minds and in the imagination of the descendants, our contemporaries. The myth of early European Empires has got actualization by an art of early times and by contemporary art. Now that myth strengthened and distributed by new electronic and digital media. Functions of that myth consist in the explication and the interpretation of the historical past of people and in the design and the programming of the future. In all myths about the historical evolution of states the Golden age is always in the past, in the time of ancestors, in the period of Empire.

In conclusion, the author underlines, the actualization of Empire's myth in contemporary culture is closely connected with imperial historical past and uncertain historical future of current European states.
\end{abstract}

Keywords: Empire, myth of Empire, political maps, mythological consciousness, imperial past

\section{INTRODUCTION}

The Empire Myth is one of the political myths now. It's very important to research the myth of Empire and mode, how the myth is actualizing and functioning in the culture now. There are numerous European countries, which have Empires historical past or imperial historical heritage, but only a few want political, cultural and economic domination now. The return to the Imperial ideology took place in the Europe after the years after the End of the Cold War and organization of European Union. It's very interesting case for the Political Study. 
IJASOS- International E-Journal of Advances in Social Sciences, Vol. III, Issue 7, April 2017

In these new political circumstances, we try to give the answers to such questions: What is the Empire Myth? Where is the root of the Empire Myth? What is the cause of actualization of Empire Myth?

\section{METHODOLOGY}

The theories of political myths in structural anthropology, semiotics and post-colonial studies by R. Bart, A. Csuladze, M. Eliade, R. Kabbani, E. Meletinskiy, G. Munkler, P. Pomper, E. Said, S. Woodford, L. D. Wurgaft are the methodologies in the process of cognition of contemporary European Myth of Empire.

The first theory about the essence and specific of contemporary political myths, which we would interpret, is the theory by M. Eliade. This conception reveals the functional essence of myth in the contemporary world. Now as always the myth is narrative about origins, heroes, feats, and Golden Ages (Eliade, 2000, http://www.aquarun.ru/psih/relig/relig1.html). This is the narrative about the sacred history of ancestors, which forms the role models for posterity. In the mind of an individual, the myth exists in the form of fantasies and dreams. His perception is deeply emotional and affective. The political myths exist in the form of artworks (Woodford, 2003). The art form of existence of political myths enhances their emotional impact. Narratives about real and fictional heroes of Empire history are repeated in the popular culture in films, novels, animations, and songs. All of this has a great power of suggestion (Wurgaft, 1983). The result of an affective, emotional and suggestive perception of such narratives, that are widespread in the popular culture, is the actualization of Empire myth in contemporary society.

Another theory of political myth function in the XX century is the theory by E. Meletinskiy. As E. Meletiskiy told us, the political myth is the primary model of ideology and a syncretic beginning of all sorts of culture. The mode of existence for Empire myths in contemporary culture is the circle process of changing period demythologization and re-mythologization. The political myths exist forever. It has function of interpretation very difficult contemporary political life in the stereotype myth model. The political "myth solves metaphysical problems maintain the harmony of personal and public, and the control of social and cosmic order" (Meletinskiy, 2000, http://www.ruthenia.ru/folklore/meletinsky1.htm). That purpose of the myth is a ritual. The ritual is repeated, practical reproduction of myth in the form of story, song, picture, dance, theatrical or films. The ritual gives the certainty to the existence of man and society in conditions of continuous change.

As Roland Bart, famous French theoretician of myths, told us, the political myth in contemporary culture transforms from imaging thinking to political demagogy. This process is due to follow factors: "disillusionment with the rationalistic philosophy, with evolutionism, and with enlightenment hopes" (Bart, 1994, p. 82). It was the process re-mythologization: "rejection from sociology and history approaches due to reveal the eternal basis of human being and thinking" (Meletinskiy, 2000, http://www.ruthenia.ru/folklore/meletinsky1.htm). There are "rehabilitation and apologyzation of mythology as an eternal symbolic expression of human being in art" (Meletinskiy, 2000, http://www.ruthenia.ru/folklore/meletinsky1.htm).

The strongly impact conception about political myth is the conception by Georgian philosopher of politics culture A. Csuladze. He analyzes the contemporary political myth as a way of political control and domination. After E. Kassirer he recognizes Mass Media as an important instrument of political manipulation of human consciousness. Electronic and digital media broadcast to the largest possible audience and their informational influence is endless. The level of trust of an audience in the conditions of "Information noise" is extremely high too. Political myth, that exists in the Mass Media, creates a new virtual political picture of the world. This information world picture as mass media picture defines the picture of everyday life of people and "constructs the self-identity of man" (Csuladze, 2014, http://www.novsu.ru/npe/files/um/1412/bg/shell/arh/mono/Цуладзе А. Политическая мифология.htm). "The political myth serves the political purposes: the struggle to the ideological power, the legitimization of power, the political domination" (Csuladze, 2014, http://www.novsu.ru/npe/files/um/1412/bg/shell/arh/mono/ htm).

Among all of the political and media myths A. Csuladze distinguishes the "technological" myths, which serves the one historical moment of times, and the "eternal" myths at all times. "Eternal" myths were founded on the ancient archetypes of common un-consciousness, they are a stable, constant and unchanging, capable of existing for a long time (Csuladze, 2014, http://www.novsu.ru/npe/files/um/1412/bg/shell/arh/mono/Цуладзе А. Политическая мифология.htm). The specifics of such myths consist in the historical roots of their narratives. National history, all historical events, and heroes are the key points of myth's story tales. Myth's story tales function as the basis for national identity development. They define the historic mission, purpose, and role in world history. Now we can see that all the events of contemporary history have become the new pages of old "eternal" myths. 


\section{RESULTS}

The myth of Empire in this classification belongs to the group of the "eternal" myths. The Empire myth is narrative about the history, the territory and the everyday life of fathers (E.Said,). These Empires of Fathers are absent today, but memory and myth of Empires continue to exist in contemporary culture. His existence is embodied in many kinds of artworks and repeated in the Mass Media Culture. We can see a lot of examples in the contemporary Russian art and media, there are such films and serials as "The Viking" (2016) in the cinema, "Sophia Palaeologus", "Peter. The will" (2011) and "Katherina the Great" (2016) on TV, and so many animation films for children about Three Russian Heroes.

The cause of actualization the Imperial consciousness and Myth of Empire is closely connected with two major social, political, economic and cultural challenges for contemporary European mode of life. The first challenge is the danger of American domination in all aspects of modern Europe life. The second challenge is the unequal partnership of the countries-participants in the European integration and politically unstable development of the South and South-East periphery of Europe. In the first point, the European Union has a risk to get the position of periphery relative to the center of Imperial American domination. In the second point, the European Union has responsible for the position of the margins. It is common practice when a supranational Union is an Empire. This isn't the case of European Union now. As authoritative German researcher, G. Munkler told us, the European Union at all not ready for these challenges today (Munkler, 2015, p. 291).

These challenges today responded to three of the actors with the most successful and old experience of Imperial control peripheral territories within the Empire and equal relations with both the existing empires of other types: The United Kingdom, Russia, and Turkey. Each of these actors has their own reasons and ways of re-mythologization Empire and ideologically formulated the mission of the Empire. The perspectives of new Empires, according to G. Munkler, depend on the suggesting power ideological mission of the Empires and Imperial myths, which have a military, economic and political resources (Munkler, 2015, p. 292). As can be seen from the presented missions, the functioning of contemporary myths of Empire is the explication and interpretation of the historical past of the countries and in the programming and creation of attractive images of the future in today's changing world.

\section{CONCLUSION}

In the end, we can conclude that the myth of Empire in the aspect of content is a political myth and this one in the aspect of form is the narrative about the sacred history of ancestors in the art and mass media culture. The specifics of such myths consist in the historical roots of their narratives. National history, all historical events, and heroes are key points of myth's story tales. The cause of the actualization of the myth of Empire in contemporary culture is closely connected with Imperial historical past and uncertain historical future of European States.

\section{REFERENCE LIST}

Bart, R. (1994). Myth today. Chosen works: Semiotics. Poetics.

Csuladze, A. (2014). Political mythology. Novgorod national university: network resource. http://www.novsu.ru/npe/files/um/1412/bg/shell/arh/mono/Цуладзе А. Политическая мифология.htm

Eliade, M. (2000). Myths of the modern world. Psychological center: network resource. http://www.aquarun.ru/psih/relig/relig1.html

Kabbani R. (1985). Europe's Myth of Empire.

Marshall L.H. (2008). National Myth and Imperial Fantasy: Representations of Britishness on the Early Eighteenth-Century Stage.

Meletinskiy, E. (2000). Myth and the XX century. Folklore and post-folklore: structure, typology, semiotics: network resource. http://www.ruthenia.ru/folklore/meletinsky1.htm

Munkler, G. (2015). Empires. The logic of domination over the world: from Ancient Rome to the USA. 
Pomper P. ( 2005). The history and theory of empires. History and Theory, Vol. 44, No. 4, Theme issue 44: Theorizing Empire.

Said E. (1993). Culture and Imperialism.

Walter D. (2008). Colonialism and Imperialism // Encyclopedia of Violence, Peace, and Conflict.

Woodford S. (2003). Images of Myths in Classical Antiquity.

Wurgaft L.D. (1983). The Imperial Imagination: Magic and Myth in Kipling's India. 